\title{
ANALISIS PENGARUH LIKUIDITAS DAN PROFITABILITAS TERHADAP STRUKTUR MODAL PADA PERUSAHAAN FOOD AND BEVERAGE DI BURSA EFEK INDONESIA
}

\author{
Agus Rahman Alamsyah \\ Jurusan Akuntansi STIE ASIA Malang, \\ J1 Soekarno Hatta (Rembuksari) Malang, \\ Telp: 08819600895 Email: agusra.080808@ gmail.
}

\begin{abstract}
This research aims to empirically examine the influence of liquidities and profitabilities to capital structure. Samples are 15 food and beverage sectors listed in Jakarta Stock Exchange (JSE) during 2006-2010. Multiple regressions are used to test hypotheses. Financial ratios used in the liquidity ratio and profitability ratio, variable in this study are independent and dependent variables. The independent variable consist of Current Ratio (CRR), Cash Ratio (CAR), Quick-acid Test Ratio (QUR), Working Capital to Total Assets Ratio (WCR), Net Profit Margin (NPM), Rate of Return on Investment (ROI), and Rate of Return for the Owner-equity (ROE), and the dependent variable consist of Debt to Equity Ration (DER) and Debt to Assets Ratio (DAR). Results show that the liquidity ratio (cash ratio and working capital to total assets ratio) have negative impact on companies' capital structure (debt to equity ratio and debt to assets ratio), but liquidity ratio is quick-acid test ratio has positive impact on companies' capital structure (debt to equity ratio and debt to assets ratio). However profitability ratio (rate of return on investment) have negative impact on capital structure (debt to equity ratio and debt to assets ratio) to support the pecking order theory. The theory stated that the higher profitability the more retained returns so capital structure become lower.
\end{abstract}

Keywords : liquidity, profitability, capital structure

\section{PENDAHULUAN}

Dalam perspektif manajemen keuangan, tujuan perusahaan adalah memaksimumkan nilai perusahaan, yang juga berarti memaksimumkan kekayaan pemegang saham. Pada sebuah perusahaan yang sudah go public, nilai sebuah perusahaan tercermin pada harga sahamnya yang diperdagangkan di bursa efek. Jika harga saham sebuah perusahaan meningkat maka nilai perusahaan tersebut juga meningkat, demikian juga dengan kekayaan pemegang sahamnya. Sebaliknya, jika harga saham perusahaan turun maka nilai perusahaan tersebut turun dan 
kekayaan pemegang sahamnya juga turun. Tujuan maksimalisasi nilai perusahaan ini harus melandasi semua keputusan yang diambil dalam perusahaan (Sartono,1998:237). Kebijakan mengenai struktur modal melibatkan tradeoff antara risiko dan tingkat pengembalian yang diharapkan. Penambahan hutang memperbesar risiko perusahaan tetapi sekaligus juga memperbesar tingkat pengembalian yang diharapkan dalam bentuk keuntungan. Risiko yang makin tinggi akibat membesarnya hutang cenderung menurunkan harga saham, tetapi meningkatnya tingkat pengembalian yang diharapkan akan menaikkan harga saham tersebut. Struktur modal yang optimal adalah struktur modal yang mengoptimalkan keseimbangan antara risiko dan pengembalian sehingga memaksimumkan harga saham. Beberapa perusahaan mempunyai nilai struktur modal yang berfluktuatif (mengalami peningkatan atau penurunan) dari tahun ke tahun yang dipengaruhi oleh beberapa faktor antara lain tingkat bunga, stabilitas earning, susunan aktiva, kadar risiko aktiva, jumlah modal yang dibutuhkan, keadaan pasar modal, sifat manajemen, dan besarnya suatu perusahaan (Riyanto,1995:297).

Peneliti menggunakan perusahaan food and beverage dikarenakan perusahaan tersebut memiliki karakteristik produk yang sering digunakan oleh banyak orang serta memiliki ketahanan dalam menghadapi berbagai kebijakan sehingga hampir dipastikan bahwa produk perusahaan tetap dibeli serta diminati oleh masyarakat. Apabila kegiatan produksi mengalami hambatan tertentu maka hal tersebut hanya dianggap sebagai bad news dan perusahaan segera melakukan perbaikan proses produksi dalam waktu yang relatif singkat. Untuk itu perusahaan harus mempertahankan faktor internal secara maksimal yaitu kemampuan mengelola struktur modal yang baik. Jika rasio keuangan likuiditas dan profitabilitas ini mempunyai pengaruh yang signifikan terhadap strukutur modal maka penelitian ini tentu akan merupakan pengetahuan yang bermanfaat bagi para pemakai laporan keuangan di perusahaan food and beverage, sebaliknya jika rasio keuangan ini ternyata tidak cukup signifikan berpengaruh terhadap struktur modal maka hasil penelitian ini akan menjadi dasar tentang inkonsistensinya hasil-hasil penelitian empiris sebelumnya.

\section{Rumusan Masalah}

Berdasarkan atas latar belakang penelitian di atas, maka rumusan masalah dalam penelitian ini adalah: 
1. Bagaimanakah pengaruh likuiditas terhadap struktur modal pada perusahaan food and beverage yang terdaftar di Bursa Efek Indonesia?

2. Bagaimanakah pengaruh profitabilitas terhadap struktur modal pada perusahaan food and beverage yang terdaftar di Bursa Efek Indonesia?

\section{Tujuan Penelitian}

Sebagaimana telah dinyatakan sebelumnya, penelitian ini dimaksudkan untuk melakukan pengujian lebih lanjut tentang penelitian-penelitian empiris yang berhubungan dengan pengaruh likuiditas dan profitabilitas terhadap struktur modal. Secara definitif, penelitian ini bertujuan untuk:

1. Mengetahui pengaruh likuiditas terhadap struktur modal pada perusahaan food and beverage yang terdaftar di Bursa Efek Indonesia.

2. Mengetahui pengaruh profitabilitas terhadap struktur modal pada perusahaan food and beverage yang terdaftar di Bursa Efek Indonesia.

\section{Landasan Teori}

\section{Analisis Rasio sebagai Dasar Penilaian Kinerja}

Menurut Sirait (1998:294), analisis laporan keuangan yang berupa rasio keuangan berguna sebagai cara untuk mengantisipasi keadaan di masa yang akan datang serta dapat dijadikan sebagai titik tolak bagi tindakan perencanaan yang akan mempengarui jalannya kejadian di masa datang, sedangkan menurut Muslich (2001:44), analisis rasio keuangan merupakan alat utama dalam analisis keuangan, karena analisis ini dapat digunakan untuk menjawab berbagai pertanyaan tentang keadaan perusahaan. Berdasarkan uraian di atas tentang analisis laporan keuangan, maka kegiatan ini berguna untuk mengantisipasi kondisi di masa mendatang dan yang lebih penting lagi adalah sebagai titik awal perencanaan kegiatan yang akan mempengaruhi di masa yang akan datang.

\section{Jenis-jenis Rasio Keuangan}

Rasio merupakan alat yang dinyatakan dalam artian relatif maupun absolut yang menjelaskan hubungan tertentu antara faktor yang lain dari suatu laporan keuangan. Adapun 
jenis-jenis rasio keuangan yang digunakan sebagai alat untuk mengukur kinerja adalah sebagai berikut:

1. Rasio likuiditas (aspek likuiditas)

Dimaksudkan untuk mengetahui kemampuan perusahaan dalam memenuhi kewajiban finansialnya yang berjangka pendek tepat pada waktunya (Sartono,1998:83). Likuiditas perusahaan ditunjukkan oleh besar kecilnya aktiva lancar yaitu aktiva yang mudah untuk diubah menjadi kas yang meliputi kas, surat berharga, piutang, dan persediaan.

a. Current Ratio, yaitu perbandingan antara aktiva lancar dengan hutang lancar yang merupakan kemampuan untuk membayar utang yang segera harus dipenuhi dengan aktiva lancar (Riyanto,1995:332). Semakin tinggi current ratio ini berarti semakin besar kemampuan perusahaan untuk memenuhi kewajiban finansial jangka pendek

$$
\text { Current Ratio }=\frac{\text { Aktiva Lancar }}{\text { Hutang Lancar }}
$$

b. Cash Ratio, yaitu perbandingan antara aktiva lancar yaitu kas dan efek dengan hutang lancar yang merupakan kemampuan untuk membayar utang yang segera harus dipenuhi dengan kas yang tersedia dalam perusahaan dan efek yang dapat segera diuangkan (Riyanto, 1995:332).

$$
\text { Cash Ratio }=\frac{\text { Kas }+ \text { Efek }}{\text { Hutang Lancar }}
$$

c. Quick (acid test) Ratio, yaitu perbandingan antara aktiva lancar yang benar-benar likuid saja, yakni aktiva lancar di luar persediaan atau dikurangi dengan persediaan dan dibandingkan dengan hutang lancar. Rasio ini merupakan alat ukur untuk menunjukkan kemampuan untuk membayar utang yang segera harus dipenuhi dengan aktiva lancar yang lebih likuid (Riyanto,1995:333).

$$
\text { Quick Ratio }=\frac{\text { Aktiva Lancar }- \text { Persediaan }}{\text { Hutang Lancar }}
$$

d. Working Capital to Total Asset Ratio, yaitu perbandingan antara aktiva lancar dikurangi hutang lancar dengan jumlah aktiva yang merupakan likuiditas dari total aktiva dan posisi modal kerja (Riyanto, 1995:333).

$$
\text { Working Capital to Total Asset }=\frac{\text { Aktiva Lancar }- \text { Hutang Lancar }}{\text { Total Aktiva }}
$$


2. Rasio Profitabilitas, dimaksudkan untuk mengetahui kemampuan perusahaan dalam menghasilkan laba baik dalam hubungannya dengan penjualan, aktiva maupun laba bagi modal sendiri (Sartono,1998:90). Untuk mengukur profitabilitas digunakan alat analisis yaitu:

a. Net Profit Margin, yaitu perbandingan antara laba bersih dengan penjualan netto yang merupakan kemampuan dari setiap penjualan untuk menghasilkan keuntungan netto (Riyanto,1995:336).

$$
\text { Net Profit Margin }=\frac{\text { Laba Bersih Setelah Pajak }}{\text { Penjualan Netto }}
$$

b. Rate of Return on Investment (ROI), yaitu perbandingan antara laba bersih dengan jumlah aktiva yang merupakan kemampuan dari modal yang diinvestasikan dalam keseluruhan aktiva untuk menghasilkan keuntungan netto (Riyanto,1995:336).

$$
\text { Rate of Return on Investment }=\frac{\text { Laba Bersih Setelah Pajak }}{\text { Total Aktiva }}
$$

c. Rate of Return for the Owner/Equity (ROE), yaitu perbandingan antara laba bersih dengan jumlah modal sendiri yang merupakan kemampuan dari modal sendiri untuk menghasilkan keuntungan bagi pemegang saham preferen dan saham biasa (Riyanto,1995:336).

$$
\text { Rate of Return for the Owner }=\frac{\text { Laba Bersih Setelah Pajak }}{\text { Jumlah Modal Sendiri }}
$$

\section{Struktur Modal.}

1. Pengertian Struktur Modal.

Menurut Riyanto (1995:13), struktur modal adalah "pembelanjaan permanen dimana mencerminkan perimbangan antara hutang jangka panjang dengan modal sendiri”. Demikian pula seperti yang dikemukakan oleh Sartono (1998:237), bahwa struktur modal adalah "perimbangan jumlah utang jangka pendek yang bersifat permanen, utang jangka panjang, saham preferen, dan saham biasa yang dipergunakan oleh perusahaan”.

Dari beberapa definisi tersebut di atas dapat kita rumuskan bahwa struktur modal adalah perimbangan antara hutang jangka panjang dan bauran antara modal yang terdiri atas 
saham preferen dan saham biasa serta dari sumber-sumber lain yaitu hutang jangka pendek sebagai pembelanjaan perusahaan.

2. Faktor-faktor yang Berpengaruh terhadap Struktur Modal

Sartono (1998:246) mengemukakan tiga pendekatan dalam struktur modal yang mendasari pembahasan struktur modal yaitu pendekatan laba bersih (net income), pendekatan laba operasi bersih (net operating income) dan pendekatan tradisional, dengan rincian sebagai berikut:

a. Pendekatan Laba Bersih (net income)

Menurut Sartono (1998:246), mengasumsikan bahwa "investor mengkapitalisasikan atau menilai laba perusahaan dengan tingkat kapitalisasi yang konstan dan perusahaan dapat meningkatkan jumlah hutangnya dengan tingkat biaya hutang yang konstan pula”. Pendekatan ini menunjukkan bahwa pertambahan leverage tidak akan mempengaruhi biaya modal sendiri dan biaya hutang, dimana pemegang saham maupun pemegang obligasi tidak mempertimbangkan risiko pendapatan yang berasal dari pertambahan hutang karena biaya modal sendiri dan biaya hutang konstan, sehingga semakin besar jumlah hutang yang digunakan perusahaan maka menyebabkan biaya modal rata-rata tertimbang perusahaan semakin kecil.

b. Pendekatan Laba Operasi Bersih (net operating income)

Menurut Sartono (1998:247), mengasumsikan bahwa "investor memiliki reaksi yang berbeda terhadap penggunaan hutang oleh perusahaan, pendekatan ini melihat bahwa biaya modal rata-rata tertimbang konstan berapapun tingkat hutang yang digunakan oleh perusahaan". Dalam pendekatan ini biaya hutang konstan walaupun leverage bertambah, sebaliknya jika biaya modal sendiri akan naik dengan pertambahan hutang. Penggunaan hutang yang semakin besar oleh pemilik modal sendiri dilihat sebagai peningkatan risiko, oleh karena itu tingkat keuntungan yang disyaratkan oleh pemilik modal sendiri akan meningkat sebagai akibat meningkatnya risiko perusahaan.

c. Pendekatan Tradisional

Menurut Sartono (1998:245), pendekatan ini mengasumsikan bahwa hingga suatu leverage tertentu, resiko perusahaan tidak mengalami perubahan, sehingga baik biaya hutang maupun biaya modal sendiri relatif konstan, namun demikian setelah leverage tertentu biaya hutang dan biaya modal sendiri meningkat, peningkatan biaya 
modal sendiri akan semakin besar dan bahkan akan lebih besar dari pada penurunan biaya karena penggunaan hutang yang lebih murah, akibatnya biaya modal rata-rata tertimbang pada awalnya menurun dan setelah leverage tertentu akan naik. Menurut pendekatan tradisional, nilai perusahaan mula-mula meningkat dan akan menurun sebagai akibat penggunaan hutang yang semakin besar, dengan demikian menurut pendekatan ini terdapat struktur modal yang optimal untuk setiap perusahaan. Struktur modal yang optimal tersebut terjadi pada saat nilai perusahaan maksimal atau biaya modal rata-rata tertimbang minimum.

Teori di atas ternyata berbeda sudut pandangnya dalam pendekatan terhadap struktur modal seperti dari penelitian oleh Kim, Ramaswamy, dan Sundaresan (1993:117131) dan Longsta-Schwartz (1995:789-821) dalam Leland (1998:1-48) menyatakan bahwa harga obligasi dengan risiko kredit tidak terkait dengan struktur modal, yang merupakan pengembangan dari Kane, Marcus dan Mc Donald (1984:841-852. Sedangkan penelitian dari Leland (1998;1-48), memberikan sebuah kesimpulan bahwa pengendalian equityholder mampu mempengaruhi struktur modal dan risiko investasi. Equityholder akan menjadi strategi dalam pengurangan nilai atas klaim, termasuk penagihan pajak pemerintah, klaim eksternal dan debtholder.

3. Struktur Modal bagi Perusahaan ditinjau dari Leverage

Berdasarkan penelitian dari Stomper dan Zulehner (2005:1-54), menyimpulkan bahwa pengaruh fundamental dari leverage tidak hanya tergantung dari laba di masa akan datang yang berupa tingkat penyesuaian atas tingkat risiko, tapi juga kondisi dimana mereka mampu memprediksi laba di masa datang. Dari penelitian tersebut dapat dibuktikan bahwa leverage mempengaruhi keputusan harga, dari analisis ini kemudian juga diperoleh hasil penelitian bahwa leverage juga berpengaruh terhadap permasalahan agensi manajerial. Penelitian ini menggambarkan tentang pentingnya mengkombinasikan berbagai macam teori tentang optimalisasi harga, investasi dan keuangan.

Dari penelitian tersebut di atas mempunyai karakteristik berbeda dengan teori yang telah dikemukakan oleh Syamsudin (2001:54), yang menyatakan bahwa perusahaan dalam menentukan suatu kebijakan yang berkaitan dengan struktur modal, harus terlebih dahulu mempertimbangkan faktor-faktornya, antara lain sebagai berikut:

a. Tingkat pertumbuhan penjualan di masa depan 
Tingkat pertumbuhan penjualan masa depan merupakan ukuran sampai sejauh mana laba per saham dari suatu perusahaan dapat ditingkatkan oleh leverage, jika penjualan meningkat maka pembiayaan melalui hutang dengan bunga tetap akan meningkatkan pendapatan pemegang saham, saham biasa suatu perusahaan yang mempunyai tingkat pertumbuhan penjualan dan laba yang baik akan mempunyai harga yang tinggi dan akan membantu pembiayaan modal. Perusahaan harus mempertimbangkan keuntungan dalam menggunakan leverage, karena adanya kesempatan untuk meningkatkan modal saham ketika harga sahamnya tinggi.

b. Stabilitas penjualan masa depan

Stabilitas penjualan dan rasio hutang berkaitan, bila stabilitas penjualan dan laba lebih besar, maka beban hutang tetap yang terjadi pada suatu perusahaan akan mempunyai risiko yang lebih kecil dibandingkan dengan perusahaan yang penjualan dan labanya menurun tajam. Bila laba kecil, maka perusahaan akan menemui kesulitan untuk membayar bunga tetap dari obligasinya.

c. Karakteristik industri

Mudahnya perusahaan baru untuk memasuki suatu industri dan kemampuan perusahaan pesaing dalam memperluas kapasitasnya, keduanya akan mempengaruhi margin laba. Industri yang berkembang menjanjikan margin laba yang tinggi tetapi margin laba tersebut cenderung turun jika industri meningkat dengan cepat dan masuknya perusahaan baru.

d. Struktur aktiva perusahaan

Struktur aktiva dapat mempengaruhi sumber-sumber pembiayaan, perusahaan yang memiliki aktiva tetap jangka panjang terutama jika permintaan akan produk mereka cukup meyakinkan, dan perusahaan yang sebagian aktivanya berupa piutang dan persediaan tidak begitu tergantung pada pembiayaan hutang jangka panjang dan lebih tergantung pada pembiayaan hutang jangka pendek.

e. Sikap pemberi pinjaman

Sikap para pemberi pinjaman menentukan struktur modal tanpa memperhatikan pendapat manajemen. Apabila perusahaan ingin menggunakan leverage tanpa batas, kreditur mungkin tidak akan bersedia untuk memberi tambahan hutang karena hutang yang terlalu besar akan mempengaruhi posisi kredit dari pinjaman dan penilaian 
kredibilitas yang dibuat sebelumnya, sebab sikap pemberi pinjaman akan mempengaruhi kebijaksanaan struktur modal perusahaan.

Nugroho (2006) dalam penelitiannya tentang analisis faktor-faktor yang mempengaruhi struktur modal perusahaan properti yang go public di Bursa Efek Jakarta, hasil penelitiannya menunjukkan bahwa; (1) secara parsial variabel Operating Leverage berpengaruh signifikan negatif terhadap variabel DER artinya peningkatan OL akan menurunkan nilai DER sehingga Operating Leverage yang tinggi akan mempunyai beban tetap yang besar sehingga perusahaan akan cenderung meminimalisasi hutang untuk mengurangi beban tetap berupa bunga, (2) secara parsial variabel CR berpengaruh signifikan positif terhadap variabel DER artinya likuiditas perusahaan akan berpengaruh terhadap hutang perusahaan, hal ini menunjukkan bahwa dengan peningkatan CR akan menambah keyakinan investor akan likuiditas perusahaan sehingga mempermudah manajemen menambah hutang dan menyebabkan DER naik, (3) secara parsial variabel STA tidak berpengaruh terhadap variabel DER, (4) secara parsial variabel Growth berpengaruh signifikan positif terhadap variabel DER, hal ini menunjukkan bahwa semakin besar pertumbuhan yang dimiliki perusahaan akan menarik perhatian investor untuk menanamkan modalnya dan mempermudah manajemen mendapatkan hutang karena adanya keyakinan investor terhadap kinerja perusahaan, (5) secara parsial variabel ROA berpengaruh signifikan negatif terhadap variabel DER, ini menunjukkan bahwa perusahaan dengan tingkat pengembalian yang tinggi atas investasi (ROA) akan menggunakan utang relatif kecil. Penelitian Titman et.al (1988) dalam Rachmawardani (2007) menjelaskan bahwa faktor-faktor penentu struktur modal adalah variabel keunikan, profitabilitas dan klasifikasi industri secara signifikan berpengaruh terhadap struktur modal, sedangkan berdasarkan penelitian Santika et.al (2002) dalam Rachmawardani (2007) menyebutkan bahwa variabel penentu struktur modal perusahaan adalah variabel ukuran perusahaan, risiko keuangan, nilai aktiva yang digunakan, profitabilitas dan tingkat bunga.

\section{Hipotesis}

Berdasarkan pada uraian di atas, maka hipotesis penelitian ini adalah:

1. Diduga likuiditas berpengaruh terhadap struktur modal secara positif pada perusahaan food and beverage yang terdaftar di Bursa Efek Indonesia. 
2. Diduga profitabilitas berpengaruh terhadap struktur modal secara negatif pada perusahaan food and beverage yang terdaftar di Bursa Efek Indonesia.

\section{Metode Penelitian}

Penelitian ini pada dasarnya adalah untuk menjelaskan pengaruh antara variabel bebas (independent variable) yaitu likuiditas dan profitabilitas terhadap variabel terikat (dependent variable) yaitu struktur modal pada perusahaan-perusahaan food and beverage yang terdaftar di Bursa Efek Indonesia di periode 2006 - 2010.

Untuk menentukan model matematis yang mencerminkan hubungan sebab akibat antara variabel bebas dan variabel terikat maka dalam penelitian ini digunakan model regresi linear berganda yang dirumuskan sebagai berikut:

1. Debt to equity ratio

$$
Y_{1}=a+b_{1.1} X_{1.1}+b_{1.2} X_{1.2}+b_{1.3} X_{1.3}+b_{1.4} X_{1.4}+b_{2.1} X_{2.1}+b_{2.2} X_{2.2}+b_{2.3} X_{2.3}+e_{i}
$$

\section{Debt to assets ratio}

$$
Y_{2}=a+b_{1.1} X_{1.1}+b_{1.2} X_{1.2}+b_{1.3} X_{1.3}+b_{1.4} X_{1.4}+b_{2.1} X_{2.1}+b_{2.2} X_{2.2}+b_{2.3} X_{2.3}+e_{i}
$$

Dimana;

$\begin{array}{ll}\mathrm{Y}_{1} & : \text { debt to equity ratio } \\ \mathrm{Y}_{2} & \text { : debt to assets ratio } \\ \mathrm{X}_{1.1} & \text { : current ratio } \\ \mathrm{X}_{1.2} & \text { : cash ratio } \\ \mathrm{X}_{1.3} & \text { : quick (acid test) ratio } \\ \mathrm{X}_{1.4} & \text { : working capital to total assets ratio } \\ \mathrm{X}_{2.1} & \text { : net profit margin } \\ \mathrm{X}_{2.2} & \text { : rate of return on investment } \\ \mathrm{X}_{2.3} & \text { : rate of return for the ownerlequity } \\ \mathrm{a} & : \text { konstanta } \\ \mathrm{b}_{1} \mathrm{~b}_{2} \mathrm{~b}_{3 \ldots .} & : \text { koefisien regresi } \\ \mathrm{e} & : \text { variabel pengganggu }\end{array}$

Populasi dalam penelitian ini adalah populasi perusahaan yang go public dan terdaftar di Bursa Efek Indonesia, dengan menggunakan purposive sampling, yaitu memilih perusahaan yang aktif terdaftar di Bursa Efek Indonesia dalam 5 tahun berturut-turut dengan jumlah perusahaan yang diolah sebanyak 15 perusahaan manufaktur di bidang makanan dan minuman (food and beverage). Adapun sumber data yang diolah adalah laporan keuangan yang meliputi; laporan 
laba rugi, neraca dan perubahan ekuitas pada perusahaan-perusahaan manufaktur di bidang makanan dan minuman (food and beverage) yang terdaftar di Bursa Efek Indonesia yang aktif selama periode 2006, 2007, 2008, 2009 dan 2010.

\section{Metode Analisis}

Dalam rangka menguji hubungan linier variabel bebas (independent variable) yaitu likuiditas dan profitabilitas terhadap variabel terikat (dependent variable) yaitu struktur modal pada perusahaan-perusahaan food and beverage yang terdaftar, sehingga diperoleh rasio-rasio keuangan yang secara signifikan dapat dijadikan sebagai prediktor struktur modal. Metode pemilihan variabel yang digunakan adalah stepwise regression dengan kriteria seleksi pada tingkat alpha $10 \%$ dan kriteria eliminasi pada tingkat alpha 12,5\%. Dengan metode ini, rasiorasio keuangan yang telah dihitung perubahan relatifnya sebagai variabel independen mula-mula dipilih yang memiliki korelasi parsial terbesar untuk kemudian diuji tingkat signifikansi hubungannya dengan struktur modal. Jika tingkat alphanya sama dengan atau lebih kecil dari kriteria seleksi 10\% maka rasio keuangan tersebut akan dimasukkan ke dalam model prediksi. Langkah berikutnya dilakukan dengan cara yang sama dengan langkah pertama, hanya saja pada setiap langkah memasukkan satu variabel ke dalam model akan dilakukan pengujian atas model yang baru terbentuk tersebut. Jika pada sejumlah rasio keuangan yang telah dimasukkan terdapat rasio keuangan yang karena pengaruh rasio keuangan lainnya memiliki tingkat alpha di atas kriteria eliminasi 12,5\%, maka rasio keuangan tersebut akan dihilangkan dari model prediksi. Langkah seleksi dan eliminasi ini akan dihentikan jika dari sekian banyak rasio keuangan yang belum dimasukkan sudah tidak ada lagi yang memiliki korelasi parsial dengan perubahan laba pada tingkat alpha yang sama dengan atau lebih kecil dari kriteria seleksi 10\%, sedangkan model prediksi yang telah terbentuk sudah tidak lagi mengandung rasio keuangan yang memiliki tingkat alpha di atas kriteria eliminasi 12,5\% (Mendenhall dan Reinmuth, 1982). Untuk analisis dan pengujian statistik dalam penelitian ini dibantu oleh program SPSS 13 for Windows.

\section{Analisis Data}

Rata-rata Rasio Likuiditas dan Profitabilitas 
Berdasarkan analisis data yang ada maka diperoleh nilai rata-rata dari masing-masing variabel likuiditas selama tahun 2006 - 2010 yang disajikan pada tabel 1 di bawah ini, yaitu;

Tabel 1. Rata-rata Rasio Likuiditas selama tahun 2006 - 2010

\begin{tabular}{|c|c|c|c|c|c|c|}
\hline \multirow{2}{*}{ NO } & \multirow{2}{*}{ KODE } & \multirow{2}{*}{ NAMA PERUSAHAAN } & \multicolumn{4}{|c|}{ Rata-rata dari 2006 - 2010} \\
\hline & & & CRR & CAR & QUR & WCA \\
\hline 1 & ADES & PT. AKASHA WIRA INTERNATIONAL, TBK (PT. AWI, TBK) & 1,03 & 0,70 & 0,94 & $(0,12)$ \\
\hline 2 & AISA & PT. TIGA PILAR SEJAHTERA FOOD, TBK & 1,03 & 0,44 & 0,42 & $(0,01)$ \\
\hline 3 & SMART & PT. SINAR MAS AGRO RESOURCES AND TECH, TBK & 1,70 & 0,17 & 1,02 & 0,21 \\
\hline 4 & MYOR & PT. MAYORA INDAH, TBK & 2,17 & 0,37 & 1,59 & 0,29 \\
\hline 5 & FAST & PT. FAST FOOD INDONESIA, TBK & 1,40 & 0,88 & 1,03 & 0,11 \\
\hline 6 & INDF & PT. INDOFOOD SUKSES MAKMUR, TBK & 1,13 & 0,48 & 0,76 & 0,03 \\
\hline 7 & STTP & PT. SIANTAR TOP, TBK & 1,61 & 0,14 & 0,73 & 0,14 \\
\hline 8 & ULTJ & PT. ULTRAJAYA MILK INDUSTRY \& TRADING, TBK & 1,96 & 0,41 & 1,13 & 0,22 \\
\hline 9 & DAVO & PT. DAVOMAS ABADI, TBK & 49,11 & 40,61 & 41,35 & 0,32 \\
\hline 10 & MLBI & PT. MULTI BINTANG INDONESIA, TBK & 0,70 & 0,37 & 0,51 & $(0,18)$ \\
\hline 11 & DLTA & PT. DELTA DJAKARTA, TBK & 4,25 & 2,18 & 3,89 & 0,60 \\
\hline 12 & SARI & PT. NIPPON INDOSARI CORPORINDO, TBK & 1,26 & 0,46 & 1,18 & 0,07 \\
\hline 13 & PTSP & PT. PIONEERINDO GOURMET INTERNATIONAL, TBK & 1,23 & 0,23 & 0,93 & 0,07 \\
\hline 14 & PSDN & PT. PRASIDHA ANEKA NIAGA, TBK & 2,13 & 0,63 & 1,07 & 0,20 \\
\hline 15 & TBLA & PT. TUNAS BARU LAMPUNG, TBK & 1,35 & 0,34 & 0,92 & 0,08 \\
\hline
\end{tabular}

Sumber Data: Diolah dari Institute for Economic and Financial Research, 2010

Tabel 1 di atas menyajikan bahwa; 1) nilai CRR rata-rata per perusahaan tertinggi dimiliki oleh PT. Davomas Abadi, Tbk yaitu sebesar 49,11\% dan nilai CRR rata-rata per perusahaan terendah dimiliki oleh PT. Multi Bintang Indonesia, Tbk yaitu sebesar 0,70\%. Hal ini menjelaskan tentang kemampuan untuk membayar hutang yang harus segera dipenuhi dengan aktiva lancar lebih besar dimiliki PT. Davomas Abadi, Tbk daripada PT. Multi Bintang Indonesia, Tbk, 2) nilai CAR rata-rata per perusahaan tertinggi dimiliki oleh PT. Davomas Abadi, Tbk yaitu sebesar 40,61\% dan nilai CAR rata-rata per perusahaan terendah dimiliki oleh PT. Siantar Top Tbk yaitu sebesar 0,14\%. Hal ini menjelaskan tentang hutang yang harus segera dipenuhi dengan kas tersedia dan efek yang segera dapat diuangkan lebih besar dimiliki oleh PT. Davomas Abadi, Tbk daripada PT. Siantar Top Tbk, 3) nilai QUR rata-rata per perusahaan tertinggi dimiliki oleh PT. Davomas Abadi, Tbk yaitu sebesar 41,35\% dan nilai QUR rata-rata per perusahaan terendah dimiliki oleh PT. Tiga Pilar Sejahtera Food, Tbk yaitu sebesar 0,42\%. 
Hal ini menjelaskan tentang hutang yang harus segera dipenuhi dengan aktiva lancar yang lebih likuid tanpa persediaan lebih besar dimiliki oleh PT. Davomas Abadi, Tbk daripada PT. Tiga Pilar Sejahtera Food, Tbk, dan 4) nilai WCA rata-rata per perusahaan tertinggi dimiliki oleh PT. Delta Djakarta, Tbk yaitu sebesar $0,60 \%$ dan nilai WCA rata-rata per perusahaan terendah dimiliki oleh PT. Multi Bintang Indonesia, Tbk yaitu sebesar -0,18\%. Hal ini menjelaskan likuiditas dari total aktiva dan posisi modal kerja lebih besar dimiliki oleh PT. Delta Djakarta, Tbk daripada PT. Multi Bintang Indonesia, Tbk. Sedangkan rata-rata rasio profitabilitas disajikan pada tabel 2 di bawah ini, yaitu:

Tabel 2. Rata-rata Rasio Profitabilitas selama tahun 2006 - 2010

\begin{tabular}{|l|l|l|c|c|c|}
\hline \multirow{2}{*}{ NO } & \multirow{2}{*}{ KODE } & \multicolumn{1}{|c|}{ NAMA PERUSAHAAN } & \multicolumn{3}{|c|}{ Rata-rata dari 2006 - 2010 } \\
\cline { 5 - 7 } & & \multicolumn{1}{|c|}{ NPM } & \multicolumn{2}{c|}{ ROI } & ROE \\
\hline 1 & ADES & PT. AKASHA WIRA INTERNATIONAL, TBK (PT. AWI, TBK) & $(0,20)$ & 30,71 & $(81,04)$ \\
\hline 2 & AISA & PT. TIGA PILAR SEJAHTERA FOOD, TBK & 0,06 & 2,64 & 8,04 \\
\hline 3 & SMART & PT. SINAR MAS AGRO RESOURCES AND TECH, TBK & 0,08 & 9,43 & 22,12 \\
\hline 4 & MYOR & PT. MAYORA INDAH, TBK & 0,06 & 9,06 & 17,89 \\
\hline 5 & FAST & PT. FAST FOOD INDONESIA, TBK & 0,06 & 16,47 & 26,65 \\
\hline 6 & INDF & PT. INDOFOOD SUKSES MAKMUR, TBK & 0,05 & 4,11 & 15,46 \\
\hline 7 & STTP & PT. SIANTAR TOP, TBK & 0,04 & 4,17 & 5,76 \\
\hline 8 & ULTJ & PT. ULTRAJAYA MILK INDUSTRY \& TRADING, TBK & 0,08 & 6,49 & 9,62 \\
\hline 9 & DAVO & PT. DAVOMAS ABADI, TBK & $(0,23)$ & $(1,21)$ & $(29,84)$ \\
\hline 10 & MLBI & PT. MULTI BINTANG INDONESIA, TBK & 0,15 & 24,32 & 112,05 \\
\hline 11 & DLTA & PT. DELTA DJAKARTA, TBK & 0,12 & 12,47 & 16,12 \\
\hline 12 & SARI & PT. NIPPON INDOSARI CORPORINDO, TBK & 0,10 & 13,42 & 28,83 \\
\hline 13 & PTSP & PT. PIONEERINDO GOURMET INTERNATIONAL, TBK & 0,03 & 5,65 & $(44,92)$ \\
\hline 14 & PSDN & PT. PRASIDHA ANEKA NIAGA, TBK & 0,03 & 4,07 & $(6,40)$ \\
\hline 15 & TBLA & PT. TUNAS BARU LAMPUNG, TBK & 0,05 & 3,61 & 10,95 \\
\hline
\end{tabular}

Sumber Data: Diolah dari Institute for Economic and Financial Research, 2010

Tabel 2 di atas menyajikan bahwa; 1) nilai NPM rata-rata per perusahaan tertinggi dimiliki oleh PT. Multi Bintang Indonesia, Tbk yaitu sebesar 0,15\% dan nilai NPM rata-rata per perusahaan terendah dimiliki oleh PT. Davomas Abadi, Tbk yaitu sebesar -0,23\%. Hal ini menjelaskan kemampuan penjualan untuk menghasilkan keuntungan lebih besar dimiliki oleh PT. PT. Multi Bintang Indonesia, Tbk daripada PT. Davomas Abadi, Tbk, 2) nilai ROI rata-rata per perusahaan tertinggi dimiliki oleh PT. Akasha Wira International, Tbk yaitu sebesar 30,71\% 
dan nilai ROI rata-rata per perusahaan terendah dimiliki oleh PT. Davomas Abadi, Tbk yaitu sebesar -1,21\%. Hal ini menjelaskan kemampuan dari modal yang diinvestasikan dalam keseluruhan aktiva untuk menghasilkan keuntungan neto lebih besar dimiliki oleh PT. Akasha Wira International, Tbk daripada PT. Davomas Abadi, Tbk, dan 3) nilai ROE rata-rata per perusahaan tertinggi dimiliki oleh PT. Multi Bintang Indonesia, Tbk yaitu sebesar 112,05 \% dan nilai ROE rata-rata per perusahaan terendah dimiliki oleh PT. Akasha Wira International, Tbk yaitu sebesar -81,04\%. Hal ini menjelaskan kemampuan dari modal sendiri yang untuk menghasilkan keuntungan bagi pemegang saham preferen dan saham biasa lebih besar dimiliki oleh PT. Multi Bintang Indonesia, Tbk daripada PT. Akasha Wira International, Tbk.

\section{Rata-rata Rasio Struktur Modal}

Berdasarkan analisis data yang ada maka diperoleh nilai rata-rata dari variabel struktur modal selama tahun 2006 - 2010 yang disajikan pada tabel 3 di bawah ini, yaitu

Tabel 3. Rata-rata Rasio Struktur Modal selama tahun 2006 - 2010

\begin{tabular}{|c|c|c|c|c|}
\hline \multirow{2}{*}{ NO } & \multirow{2}{*}{ KODE } & \multirow{2}{*}{ NAMA PERUSAHAAN } & \multicolumn{2}{|c|}{ Rata-rata dari 2006 - 2010} \\
\hline & & & DER & DAR \\
\hline 1 & ADES & PT. AKASHA WIRA INTERNATIONAL, TBK (PT. AWI, TBK) & 0,50 & 1,57 \\
\hline 2 & AISA & PT. TIGA PILAR SEJAHTERA FOOD, TBK & 0,60 & 1,73 \\
\hline 3 & SMART & PT. SINAR MAS AGRO RESOURCES AND TECH, TBK & 0,55 & 1,22 \\
\hline 4 & MYOR & PT. MAYORA INDAH, TBK & 0,48 & 0,98 \\
\hline 5 & FAST & PT. FAST FOOD INDONESIA, TBK & 0,39 & 0,64 \\
\hline 6 & INDF & PT. INDOFOOD SUKSES MAKMUR, TBK & 0,60 & 2,59 \\
\hline 7 & STTP & PT. SIANTAR TOP, TBK & 0,32 & 0,49 \\
\hline 8 & ULTJ & PT. ULTRAJAYA MILK INDUSTRY \& TRADING, TBK & 0,36 & 0,57 \\
\hline 9 & DAVO & PT. DAVOMAS ABADI, TBK & 0,77 & 4,10 \\
\hline 10 & MLBI & PT. MULTI BINTANG INDONESIA, TBK & 0,68 & 5,88 \\
\hline 11 & DLTA & PT. DELTA DJAKARTA, TBK & 0,19 & 0,28 \\
\hline 12 & SARI & PT. NIPPON INDOSARI CORPORINDO, TBK & 0,26 & 1,07 \\
\hline 13 & PTSP & PT. PIONEERINDO GOURMET INTERNATIONAL, TBK & 0,34 & 22,28 \\
\hline 14 & PSDN & PT. PRASIDHA ANEKA NIAGA, TBK & 0,29 & 1,60 \\
\hline 15 & TBLA & PT. TUNAS BARU LAMPUNG, TBK & 0,29 & 1,77 \\
\hline
\end{tabular}

Sumber Data: Diolah dari Institute for Economic and Financial Research, 2010

Tabel 3 di atas menyajikan bahwa; 1) nilai DER rata-rata per perusahaan tertinggi dimiliki oleh PT. Davomas Abadi, Tbk yaitu sebesar 0,77\% dan nilai DER rata-rata per 
perusahaan terendah dimiliki oleh PT. Delta Djakarta, Tbk yaitu sebesar 0,19\%. Hal ini menjelaskan tentang hutang lancar dan hutang jangka panjang yang akan dijamin oleh modal sendiri lebih besar dimiliki oleh PT. Davomas Abadi, Tbk daripada PT. Delta Djakarta, Tbk, dan 2) nilai DAR rata-rata per perusahaan tertinggi dimiliki oleh PT. Pioneerindo Gourmet International, Tbk yaitu sebesar $22,28 \%$ dan nilai DAR rata-rata per perusahaan terendah dimiliki oleh PT. Delta Djakarta, Tbk yaitu sebesar 0,28 \%. Hal ini menjelaskan tentang hutang lancar dan hutang jangka panjang yang akan dijamin oleh aktiva lebih besar dimiliki PT. Pioneerindo Gourmet International, Tbk daripada PT. Delta Djakarta, Tbk.

\section{Analisis Hasil Penelitian}

\section{Uji Asumsi Klasik}

1. Pengujian Asumsi Klasik Multikolinearitas

Berdasarkan desain penelitian di atas maka hasil penelitian atas rasio-rasio keuangan dapat disajikan pada Tabel 4 sebagai hasil pengujian multikolineratisas untuk $\mathrm{Y}_{1}$ yaitu:

Tabel 4. Hasil Pengujian Multikolinearitas untuk $Y_{1}$

\begin{tabular}{|c|c|c|c|c|c|c|c|c|c|}
\hline & & DER & CRR & CAR & QUR & WCA & NPM & ROI & ROE \\
\hline \multirow[t]{8}{*}{$\begin{array}{l}\text { Pearson } \\
\text { Correlation }\end{array}$} & & 1,000 &,- 550 &,- 268 &,- 421 &,- 815 & ,428 & ,568 & 731 \\
\hline & CRR &,- 550 & 1,000 & ,769 & ,848 & ,719 &,- 614 &,- 590 &,- 420 \\
\hline & CAR &,- 268 & ,769 & 1,000 & ,749 & ,434 &,- 814 &,- 452 &,- 420 \\
\hline & QUR &,- 421 & ,848 & ,749 & 1,000 & ,656 &,- 787 &,- 536 &,- 469 \\
\hline & WCA &,- 815 & ,719 & ,434 & ,656 & 1,000 &,- 331 &,- 745 &,- 431 \\
\hline & NPM &, 428 &,- 614 &,- 814 &,- 787 &,- 331 & 1,000 & ,255 & 815 \\
\hline & ROI & ,568 &,- 590 &,- 452 &,- 536 &,- 745 &, 255 & 1,000 &, 311 \\
\hline & ROE & ,731 &,- 420 &,- 420 &,- 469 &,- 431 & 815 &, 311 & 1,000 \\
\hline
\end{tabular}

Sumber: Diolah Peneliti, 2011/2012

Dilihat dari besaran nilai korelasi, nilai tertinggi 0,848 atau sekitar 84,8\% karena masih di bawah $90 \%$ maka dapat dikatakan tidak terjadi multikolinearitas yang nyata. Sedangkan pada Tabel 5 di bawah ini disajikan hasil pengujian multikolineratisas untuk $\mathrm{Y}_{2}$ yaitu: 
Tabel 5. Hasil Pengujian Multikolinearitas untuk $Y_{2}$

\begin{tabular}{|c|c|c|c|c|c|c|c|c|c|}
\hline & DAR & CRR & CAR & QUR & WCA & NPM & ROI & ROE \\
\hline \multirow{8}{*}{$\begin{array}{l}\text { Pearson } \\
\text { Correlation }\end{array}$} & DAR & 1,000 &,- 479 &,- 085 &,- 296 &,- 842 & ,171 & 493 & ,489 \\
\hline & CRR &,- 479 & 1,000 & ,769 & ,848 & ,719 &,- 614 &,- 590 &,- 420 \\
\hline & CAR &,- 085 &, 769 & 1,000 & 849 & ,434 &,- 814 &,- 452 &,- 420 \\
\hline & QUR &,- 296 & 848 &, 849 & 1,000 & ,656 &,- 787 &,- 536 &,- 469 \\
\hline & WCA &,- 842 &, 719 & ,434 & ,656 & 1,000 &,- 331 &,- 745 &,- 431 \\
\hline & NPM & ,171 &,- 614 &,- 814 &,- 787 &,- 331 & 1,000 & ,255 & ,815 \\
\hline & ROI & ,493 & -,590 &,- 452 &,- 536 &,- 745 & ,255 & 1,000 & ,311 \\
\hline & ROE & ,489 &,- 420 &,- 420 &,- 469 &,- 431 & ,815 &, 311 & 1,000 \\
\hline
\end{tabular}

Sumber: Diolah Peneliti, 2011/2012

Dilihat dari besaran nilai korelasi, nilai tertinggi 0,85 atau sekitar $85 \%$ karena masih di bawah 90\% maka dapat dikatakan tidak terjadi multikolinearitas yang nyata.

2. Pengujian Asumsi Klasik Heteroskedastisitas

Berdasarkan atas korelasi koefisien Spearman maka dapat disimpulkan bahwa antara variabel bebas $\mathrm{X}_{1.1}$ (current ratio), $\mathrm{X}_{1.2}$ (cash ratio), $\mathrm{X}_{1.3}$ (quick-acid test ratio), $\mathrm{X}_{2.1}$ (net profit margin), $\mathrm{X}_{2.2}$ (rate of return on investment), $\mathrm{X}_{2.3}$ (rate of return for the ownerequit) mempunyai korelasi dibawah 0,7 sehingga tidak terdapat heteroskedastisitas.

\section{Analisis Regresi Berganda $\mathbf{Y}_{1}$}

Sebagaimana telah dikemukakan di depan bahwa dalam penelitian ini adalah untuk mengetahui pengaruh likuiditas yang terdiri dari $\mathrm{X}_{1.1}$ (current ratio/CRR), $\mathrm{X}_{1.2}$ (cash ratio/CAR), $\mathrm{X}_{1.3}$ (quick-acid test ratio/QUR), $\mathrm{X}_{1.4}$ (working capital to total assets ratio/WCR), dan profitabilitas yang terdiri dari $\mathrm{X}_{2.1}$ (net profit margin/NPM), $\mathrm{X}_{2.2}$ (rate of return on investment/ROI), $\mathrm{X}_{2.3}$ (rate of return for the owner-equity/ROE) terhadap struktur modalnya yaitu $\mathrm{Y}_{1}$ (debt to equity ratio/DER). Adapun hasil analisis regresi berganda melalui uji t untuk $\mathrm{Y}_{1}$ disajikan pada Tabel 6. yaitu: 
Tabel 6. Hasil Analisis Regresi Berganda untuk $\mathbf{Y}_{1}$

\begin{tabular}{|l|c|c|c|c|l|}
\hline Variabel Independen & $\begin{array}{l}\text { Koefisien } \\
\text { Regresi }\end{array}$ & $\begin{array}{c}\mathbf{t} \\
\text { statistic }\end{array}$ & Signifikansi & $\begin{array}{l}\text { t tabel } \\
\mathbf{( 0 , 0 1}\end{array}$ & Keterangan \\
\hline Konstanta & 0,569 & 0,697 & 0,508 & & \\
\hline CRR $\left(\mathrm{X}_{1.1}\right)$ & $-0,105$ & $-0,808$ & 0,446 & 2,977 & Ha ditolak \\
\hline CAR $\left(\mathrm{X}_{1.2}\right)$ & $-1,931$ & $-5,285$ & 0,001 & 2,977 & Ha diterima \\
\hline QUR $\left(\mathrm{X}_{1.3}\right)$ & 4,124 & 4,228 & 0,004 & 2,977 & Ha diterima \\
\hline WCR $\left(\mathrm{X}_{1.4}\right)$ & $-18,692$ & $-5,260$ & 0,001 & 2,977 & Ha diterima \\
\hline NPM $\left(\mathrm{X}_{2.1}\right)$ & 7,911 & 0,854 & 0,421 & 2,977 & Ha ditolak \\
\hline ROI $\left(\mathrm{X}_{2.2}\right)$ & $-0,052$ & $-3,036$ & 0,019 & 2,977 & Ha diterima \\
\hline ROE $\left(\mathrm{X}_{2.3}\right)$ & 0,006 & 0,395 & 0,705 & 2,977 & Ha ditolak \\
\hline
\end{tabular}

Sumber: Diolah Peneliti, 2011/2012

Dari hasil pengujian di atas, maka dapat disimpulkan bahwa tidak seluruh variabel independen secara signifikan berpengaruh terhadap variabel dependen yaitu untuk variabel likuiditas terdiri dari $\mathrm{X}_{1.2}$ (cash ratio/CAR), $\mathrm{X}_{1.3}$ (quick-acid test ratio/QUR), $\mathrm{X}_{1.4}$ (working capital to total assets ratio/WCR), dan variabel profitabilitas yang terdiri dari $\mathrm{X}_{2.2}$ (rate of return on investment/ROI), hal ini dapat dilihat dari $t_{\text {hitung }}>t_{\text {tabel }}$ sebesar 2,977. Jika dibentuk dalam model matematis adalah sebagai berikut:

$$
\begin{aligned}
Y_{1}= & 0,569-0,105 X_{1.1}-1,931 X_{1.2}+4,124 X_{1.3}-18,692 X_{1.4}+7,911 X_{2.1}- \\
& 0,052 X_{2.2}+0,006 X_{2.3}
\end{aligned}
$$

Keterangan:

$\mathrm{Y}_{1} \quad=$ debt to equity ratio

$\mathrm{X}_{1.1}=$ current ratio

$\mathrm{X}_{1.2}=$ cash ratio

$\mathrm{X}_{1.4}=$ working capital to total assets ratio

$\mathrm{X}_{2.1}=$ net profit margin

$\mathrm{X}_{2.2}=$ rate of return on investment

$\mathrm{X}_{2.3}=$ rate of return for the owner-equity

Dari regresi linear berganda tersebut di atas dapat diartikan bahwa:

1. Konstanta 0,569 menyatakan bahwa jika tidak ada $X_{1.1}, X_{1.2}, X_{1.3}, X_{1.4}$ dan $X_{2.1}, X_{2.2}, X_{2.3}$ maka nilai $Y_{1}$ adalah Rp. 0,569,-

2. Koefisien regresi $X_{1.1}$ (current ratio) adalah $-0,105$ yang menyatakan bahwa setiap penambahan Rp. 1 maka cash ratio akan mampu menurunkan $\mathrm{Y}_{1}$ sebesar 0,105.

3. Koefisien regresi $\mathrm{X}_{1.2}$ (cash ratio) adalah $-1,931$ yang menyatakan bahwa setiap penambahan Rp. 1 maka cash ratio akan mampu menurunkan $\mathrm{Y}_{1}$ sebesar 1,931. 
4. Koefisien regresi $\mathrm{X}_{1.3}$ (quick-acid test ratio) adalah 4,124 yang menyatakan bahwa setiap penambahan Rp. 1 maka quick-acid test ratio akan mampu meningkatkan $\mathrm{Y}_{1}$ sebesar 4,124.

5. Koefisien regresi $\mathrm{X}_{1.4}$ (working capital to total assets ratio) adalah -18,692 yang menyatakan bahwa setiap penambahan Rp. 1 maka working capital to total assets ratio akan menurunkan $\mathrm{Y}_{1}$ sebesar 18,692.

6. Koefisien regresi $\mathrm{X}_{2.1}$ (net profit margin) adalah 7,911 yang menyatakan bahwa setiap penambahan Rp. 1 maka net profit margin akan mampu meningkatkan $\mathrm{Y}_{1}$ sebesar 7,911.

7. Koefisien regresi $\mathrm{X}_{2.2}$ (rate of return on investment) adalah -0,052 yang menyatakan bahwa setiap penambahan Rp. 1 maka rate of return on investment akan mampu menurunkan $\mathrm{Y}_{1}$ sebesar 0,052 .

8. Koefisien regresi $\mathrm{X}_{2.3}$ (rate of return for the owner-equity) adalah 0,006 yang menyatakan bahwa setiap penambahan $\mathrm{Rp} .1$ maka $r$ rate of return for the owner-equity akan mampu meningkatkan $\mathrm{Y}_{1}$ sebesar 0,006 .

\section{Uji ANOVA $Y_{1}$}

Uji F dilakukan untuk mengetahui bagaimana pengaruh variabel independen terhadap variabel dependen yaitu $\mathrm{Y}_{1}$ yang disajikan pada Tabel 7 di bawah ini;

Tabel 7. Anova $Y_{1}$

\begin{tabular}{|l|l|r|r|r|r|r|}
\hline & & Sum of Squares & Df & Mean & & \\
Square & \multicolumn{1}{c|}{ F } & Sig. \\
\hline $1 \quad$ Regression & 47,588 & 7 & 6,798 & 68,025 &, $000(\mathrm{a})$ \\
& Residual &, 700 & 7 &, 100 & & \\
& Total & 48,287 & 14 & & & \\
\hline
\end{tabular}

a Predictors: (Constant), ROE, ROI, CAR, WCA, CRR, QUR, NPM

b Dependent Variable: DER

Sumber: Diolah Peneliti, 2011/2012

Pada tabel 7 di atas diketahui nilai $\mathrm{F}$ hitung 68,025 sedangkan nilai $\mathrm{F}$ tabel 4,28, jadi $\mathrm{F}_{\text {hitung }}>\mathrm{F}_{\text {tabel }}$ artinya variabel-variabel independen yang diteliti secara simultan mempengaruhi debt to equity ratio (DER). Nilai signifikansinya bernilai 0,000 lebih kecil dari tingkat signifikansinya 0,01, artinya signifikan. Hasil uji $\mathrm{F}$ menunjukkan bahwa hipotesis pertama menghasilkan penolakan Ho dan penerimaan Ha artinya variabel-variabel independen yang diteliti secara simultan berpengaruh signifikan terhadap debt to equity ratio (DER). 


\section{Analisis Regresi Berganda $\mathbf{Y}_{2}$}

Adapun hasil analisis regresi berganda melalui uji t untuk $\mathrm{Y}_{2}$ disajikan pada Tabel 8. yaitu:

Tabel 8. Hasil Analisis Regresi Berganda untuk $\mathbf{Y}_{2}$

\begin{tabular}{|l|c|c|c|l|l|}
\hline Variabel Independen & $\begin{array}{l}\text { Koefisien } \\
\text { Regresi }\end{array}$ & $\begin{array}{c}\mathbf{t} \\
\text { statistic }\end{array}$ & Signifikansi & $\begin{array}{l}\text { t tabel } \\
\mathbf{( 0 , 0 1 )}\end{array}$ & Keterangan \\
\hline Konstanta & 0,362 & 1,028 & 0,338 & & \\
\hline CRR $\left(\mathrm{X}_{1.1}\right)$ & $-0,034$ & $-0,601$ & 0,567 & 2,977 & Ha ditolak \\
\hline CAR $\left(\mathrm{X}_{1.2}\right)$ & $-0,905$ & $-5,741$ & 0,001 & 2,977 & Ha diterima \\
\hline QUR $\left(\mathrm{X}_{1.3}\right)$ & 2,552 & 6,063 & 0,001 & 2,977 & Ha diterima \\
\hline WCR $\left(\mathrm{X}_{1.4}\right)$ & $-12,529$ & $-8,169$ & 0,000 & 2,977 & Ha diterima \\
\hline NPM $\left(\mathrm{X}_{2.1}\right)$ & 10,005 & 2,503 & 0,041 & 2,977 & Ha ditolak \\
\hline ROI $\left(\mathrm{X}_{2.2}\right)$ & $-0,038$ & $-5,111$ & 0,001 & 2,977 & Ha diterima \\
\hline ROE $\left(\mathrm{X}_{2.3}\right)$ & $-0,013$ & $-1,894$ & 0,100 & 2,977 & Ha ditolak \\
\hline Sumb
\end{tabular}

Sumber: Diolah Peneliti, 2011/2012

Dari hasil pengujian di atas, maka dapat disimpulkan bahwa tidak seluruh variabel independen secara signifikan berpengaruh terhadap variabel dependen yaitu untuk variabel likuiditas terdiri dari $\mathrm{X}_{1.2}$ (cash ratio/CAR), $\mathrm{X}_{1.3}$ (quick-acid test ratio/QUR), $\mathrm{X}_{1.4}$ (working capital to total assets ratio/WCR), dan variabel profitabilitas yang terdiri dari $\mathrm{X}_{2.2}$ (rate of return on investment/ROI), hal ini dapat dilihat dari $t_{\text {hitung }}>t_{\text {tabel }}$ sebesar 2,977. Jika dibentuk dalam model matematis adalah sebagai berikut:

$$
\begin{aligned}
Y_{2}= & 0,362-0,034 X_{1.1}-0,905 X_{1.2}+2,552 X_{1.3}-12,529 X_{1.4}+10,005 \\
& X_{2.1}-0,038 X_{2.2}-0,013 X_{2.3}
\end{aligned}
$$

Keterangan:

$\mathrm{Y}_{1} \quad=$ debt to assets ratio

$\mathrm{X}_{1.1}=$ current ratio

$\mathrm{X}_{1.2}=$ cash ratio

$\mathrm{X}_{1.4}=$ working capital to total assets ratio

$\mathrm{X}_{2.1}=$ net profit margin

$\mathrm{X}_{2.2}=$ rate of return on investment

$\mathrm{X}_{2.3}=$ rate of return for the owner-equity

Dari regresi linear berganda tersebut di atas dapat diartikan bahwa: 
$\checkmark$ Konstanta 0,362 menyatakan bahwa jika tidak ada $\mathrm{X}_{1.1}, \mathrm{X}_{1.2}, \mathrm{X}_{1.3}, \mathrm{X}_{1.4}$ dan $\mathrm{X}_{2.1}, \mathrm{X}_{2.2}, \mathrm{X}_{2.3}$ maka nilai $\mathrm{Y}_{2}$ adalah Rp. 0,362,-.

$\checkmark$ Koefisien regresi $\mathrm{X}_{1.1}$ (current ratio) adalah -0,034 yang menyatakan bahwa setiap penambahan Rp. 1 maka current ratio akan mampu menurunkan $\mathrm{Y}_{2}$ sebesar 0,034..

$\checkmark$ Koefisien regresi $\mathrm{X}_{1.2}$ (cash ratio) adalah -0,905 yang menyatakan bahwa setiap penambahan Rp. 1 maka cash ratio akan mampu menurunkan $\mathrm{Y}_{2}$ sebesar 0,905.

$\checkmark$ Koefisien regresi $X_{1.3}$ (quick-acid test ratio) adalah 2,552 yang menyatakan bahwa setiap penambahan Rp. 1 maka cash ratio akan mampu meningkatkan $\mathrm{Y}_{2}$ sebesar 2,552.

$\checkmark$ Koefisien regresi $\mathrm{X}_{1.4}$ (working capital to total assets ratio) adalah -12,529 yang menyatakan bahwa setiap penambahan Rp. 1 maka working capital to total assets ratio akan menurunkan $\mathrm{Y}_{2}$ sebesar 12,529.

$\checkmark$ Koefisien regresi $\mathrm{X}_{2.1}$ (net profit margin) adalah 10,005 yang menyatakan bahwa setiap penambahan Rp. 1 maka net profit margin akan mampu meningkatkan $\mathrm{Y}_{2}$ sebesar 10,005 .

$\checkmark$ Koefisien regresi $\mathrm{X}_{2.2}$ (rate of return on investment) adalah -0,038 yang menyatakan bahwa setiap penambahan Rp. 1 maka rate of return on investment akan mampu menurunkan $\mathrm{Y}_{2}$ sebesar 0,038.

$\checkmark$ Koefisien regresi $\mathrm{X}_{2.3}$ (rate of return for the owner-equity) adalah -0,013 yang menyatakan bahwa setiap penambahan Rp. 1 maka $r$ rate of return for the owner-equity akan mampu menurunkan $\mathrm{Y}_{2}$ sebesar 0,013 .

\section{Uji ANOVA $Y_{2}$}

Uji F dilakukan untuk mengetahui bagaimana pengaruh variabel independen terhadap variabel dependen yaitu $\mathrm{Y}_{2}$ yang diisajikan pada Tabel 9 di bawah ini;

Tabel 9. Anova $Y_{2}$

\begin{tabular}{|c|c|c|c|c|c|c|}
\hline & Model & $\begin{array}{c}\text { Sum of } \\
\text { Squares }\end{array}$ & Df & Mean Square & $\mathbf{F}$ & Sig. \\
\hline \multirow[t]{3}{*}{1} & Regression & 9,823 & 7 & 1,403 & 75,400 & ,000(a) \\
\hline & Residual &, 130 & 7 & ,019 & & \\
\hline & Total & 9,953 & 14 & & & \\
\hline
\end{tabular}

a Predictors: (Constant), ROE, ROI, CAR, WCA, CRR, QUR, NPM

b Dependent Variable: DAR

Sumber: Diolah Peneliti, 2011/2012 
Pada tabel di atas diketahui nilai $\mathrm{F}$ hitung 75,400 sedangkan nilai $\mathrm{F}$ tabel 4,28, jadi $F_{\text {hitung }}>F_{\text {tabel }}$ artinya variabel-variabel independen yang diteliti secara simultan mempengaruhi debt to assets ratio (DAR). Nilai signifikansinya bernilai 0,000 lebih kecil dari tingkat signifikansinya 0,01 artinya signifikan. Hasil uji $\mathrm{F}$ menunjukkan bahwa hipotesis kedua menghasilkan penolakan Ho dan penerimaan $\mathrm{Ha}$ artinya variabel-variabel independen yang diteliti secara simultan berpengaruh signifikan terhadap debt to assets ratio.

Berdasarkan hasil penelitian yang telah dilakukan, maka pengujian penelitian ini kembali menegaskan salah satu implikasi teori trade off yang menyatakan bahwa perusahaan yang dapat segera mengembalikan hutang-hutangnya akan mendapat kepercayaan yang tinggi dari pemilik modal atau kreditur. Para pemilik modal tidak akan segan-segan untuk mengucurkan modalnya dengan melihat tingkat likuiditas perusahaan, sebaliknya bagi perusahaan yang mendapat kucuran dana akan memanfaatkan kesempatan tersebut untuk mengembangkan perusahaan. Dengan demikian akan ada hubungan saling membutuhkan diantara keduanya, walaupun secara teoritis dikatakan bahwa struktur modal perusahaan yang didominasi oleh sumber dana hutang yang besar akan sangat mengkhawatirkan tingkat likuditasnya. Berdasarkan hasil penelitian di atas diperoleh informasi bahwa variabel likuiditas yaitu cash ratio dan working capital to total assets ratio berpengaruh negatif terhadap struktur modal yaitu debt to equity ratio dan debt to assets ratio, dimana setiap kenaikan cash ratio dan working capital to total assets ratio akan menurunkan nilai struktur modal yaitu debt to equity ratio dan debt to assets ratio, akan tetapi variabel likuiditas yaitu quick-acid test ratio berpengaruh positif terhadap nilai struktur modal yaitu debt to equity ratio dan debt to assets ratio, dimana setiap kenaikan quick-acid test ratio maka akan meningkatkan nilai debt to equity ratio dan debt to assets ratio.

Koefisien profitabilitas yang negatif dari hasil penelitian ini sesuai dengan teori pecking order yang berargumentasi bahwa semakin tinggi profitabilitas maka akan semakin banyak laba yang di tahan sehingga struktur modal semakin rendah, dari penelitian ini diperoleh informasi bahwa variabel profitabilitas yaitu rate of return on investment berpengaruh negatif terhadap struktur modal yaitu debt to equity ratio dan debt to assets ratio, dimana setiap kenaikan rate of return on investment akan menurunkan nilai debt to equity ratio dan debt to assets ratio. 


\section{SIMPULAN}

Berdasarkan atas penelitian yang telah di bahas di atas, maka ada beberapa temuan penelitian dengan ringkasan sebagai berikut: (1) Penelitian ini menemukan serta mendukung bukti secara statistik bahwa rasio likuiditas dan profitabilitas dapat digunakan sebagai prediktor yang berpengaruh secara signifikan terhadap struktur modal, hal ini menggambarkan bahwa kemampuan mengelola variabel likuiditas dan profitabilitas yang maksimal akan menciptakan struktur modal yang optimal dan tercapainya nilai perusahaan. (2) Berdasarkan atas hasil uji F menunjukkan bahwa hipotesis pertama menghasilkan penolakan Ho dan penerimaan Ha artinya variabel-variabel independen yang diteliti secara simultan berpengaruh signifikan terhadap debt to equity ratio, sedangkan berdasarkan hasil uji t dapat disimpulkan bahwa variabel independen secara signifikan berpengaruh terhadap variabel dependen yaitu untuk variabel likuiditas terdiri dari $\mathrm{X}_{1.2}$ (cash ratio/CAR), $\mathrm{X}_{1.3}$ (quick-acid test ratio/QUR), $\mathrm{X}_{1.4}$ (working capital to total assets ratio/WCR), dan variabel profitabilitas yang terdiri dari $\mathrm{X}_{2.2}$ (rate of return on investment/ROI). (3) Berdasarkan atas hasil uji F menunjukkan bahwa hipotesis kedua menghasilkan penolakan Ho dan penerimaan Ha artinya variabel-variabel independen yang diteliti secara simultan berpengaruh signifikan terhadap debt to assets ratio, sedangkan berdasarkan hasil uji t dapat disimpulkan bahwa variabel independen secara signifikan berpengaruh terhadap variabel dependen yaitu untuk variabel likuiditas terdiri dari $\mathrm{X}_{1.2}$ (cash ratio/CAR), $\mathrm{X}_{1.3}$ (quick-acid test ratio/QUR), $\mathrm{X}_{1.4}$ (working capital to total assets ratio/WCR), dan variabel profitabilitas yang terdiri dari $\mathrm{X}_{2.2}$ (rate of return on investment/ROI).

\section{Daftar Pustaka}

Kane, A., A. Marcus, and Robert McDonald. 1984. How Big is The Tax Advantage to Debt?, Journal of Finance 39, pp. 841-852.

Kim, In Joon., Krishna Ramaswamy, dan Suresh Sundaresan. 1993. Does Default Risk Coupons Affect the Valuation of Corporate Bonds?: A Contingent Claims Model, Financial Management 22, pp. 117-131.

Leland, Hayne E, 1998, Agency Costs, Risk Management and Capital Structure, http://www.haas.berkeley.edu/finance/WP/rpf278.pdf. pp. 1-48. 
Longsta, Francis, dan Schwartz. 1995. A Simple Approach to Valuting Rsky Debt, Journal of Finance 50, pp. 789-821.

Muslich, 2001, Manajemen Keuangan Modern, Liberty, Yogyakarta.

Nugroho, Asih Suko. 2006. ”Analisis Faktor-faktor yang Mempengaruhi Struktur Modal Perusahaan Properti yang Go-public di Bursa Efek Jakarta untuk Periode Tahun 1994-2004”, Tesis Program Pasca Sarjana, Prodi Magister Manajemenm Universitas Diponegoro.

Rachmawardani, Yulinda. 2007. "Analisis Pengaruh Aspek Likuditas, Risiko Bisnis, Profitabilitas, dan pertumbuhan Penjualan terhadap Struktur Modal Perusahaan", Tesis Program Pasca Sarjana, Prodi Magister Manajemen, Universitas Diponegoro.

Riyanto, Bambang, 1995, Dasar-dasar Pembelanjaan Perusahaan, Edisi Keempat, Cetakan Ketiga, Yayasan Badan Penerbit Gadjah Mada, Yogyakarta.

Sartono, Agus. 1998. Manajemen Keuangan, Teori Dan Aplikasi, Edisi Ketiga, Cetakan Ketiga, Yogyakarta.

Sirait, Alfonsus. 1998. Analisa Laporan Keuangan, PT. Raja Grafindo Persada, Jakarta,

Syamsuddin, Lukman. 2001. Manajemen Keuangan Perusahaan, Banyu Media Publishing, Malang. 